\title{
Även om det inte hände är det sant - Houston, We Have a Problem!
}

\author{
Sanjin Pejković* \\ Högskolan Dalarna, Sverige
}

\begin{abstract}
Even if it didn't happen, it's true" - Houston, We Have a Problem!
Houston, We Have a Problem! (director: Žiga Virc, 2016) is a mockumentary film from Slovenia that stirred up controversy in the former Yugoslavia. The film deals with the Yugoslav space program, which Josip Broz Tito sells to the United States under President Kennedy for $\$ 2.5$ billion. However, it turns out that the Yugoslavs have nothing to sell: their space program is utterly useless. The payment is then converted into a loan, forcing Yugoslavia into an economic crisis. Tito dies, and with more or less direct involvement from the US side, Yugoslavia dies with him. The content of this film, and the debate surrounding it, show that popular culture dealing with the past has inherited traces of the ideologizations of the past. This article presents interpretations of public reactions to the film, but also analyzes what it seeks to convey regarding Yugoslav historiography, through this fable of Yugoslavia, its purported space program, and US involvement.
\end{abstract}

Keywords: Houston we have a problem, documentary film, mockumentary film, Slavoj Žižek, Josip Broz Tito, Yugoslavia, Yugoslav history

2012 lanserades en bombastisk trailer i vilken det påstods att den jugoslaviske presidenten Josip Broz Tito spelade en aktiv roll i kalla krigets kamp om att erövra rymden. I trailern hör vi en röst berätta att Jugoslavien var den bortglömda tredje parten i rymdkapplöpningen, samtidigt som klipp visas på Tito, raketer och en underjordisk bas. Den otroliga berättelsen om Jugoslaviens hemliga rymdprogram blev en viral succé (Taylor, 2012). Trailern sågs av en miljon människor på en vecka (Harm, 2014). Nyheten nådde även det amerikanska Smithsonian-institutet som ombads kommentera uppgifterna (Solash, 2012; Bradbury, 2012). Den slovenske regissören Boštjan Virc blev intervjuad på nyheterna i den statliga kroatiska tv-kanalen $H R T$ (HRT 1, 2012). Han berättade att den icke-färdigställda filmen hade baserats på en hypotes som skulle komma att avslöjas i själva filmen med hjälp av dittills okända arkivklipp och fakta. Denna kombination av mild ironi och sensationalism ledde till att publiken generellt inte visste hur den skulle förhålla sig till filmens tema och nya

\footnotetext{
^Kontaktinformasjon: Sanjin Pejković, e-post: sanjinpejkovic@gmail.com 
rön. Skeptiska och övertygade röster, kommentarer och delningar i sociala medier ökade nyfikenheten (Solash, 2012; Barry, 2012). Filmens premiär var satt till våren 2013 men den kom först 2016. Filmmakarna skulle senare påstå att väntan var nödvändig på grund av materialinsamlingen (HRT 1, 2012). Filmen är en av få postjugoslaviska verk som lyckats locka både en inhemsk och en utländsk publik genom att visas på internationella filmfestivaler och finnas på Netflix.

Houston, We Have a Problem! (Žiga Virc, 2016) skulle i efterhand visa sig vara en mockumentär. Filmens innehåll och de diskussioner som omgärdade den visar på en intressant ideologisering av det förflutna. Vad försöker filmen säga om historien som aldrig hade inträffat? Hur har den tolkats och varför? Vad kan Houston, We Have a Problem! berätta om det gemensamma förflutna och vad kan läsas in i den kontrafaktiska historieskrivningen?

\section{Mockumentärfilm}

Mockumentärfilm kan förefalla vara en lättigenkännlig audiovisuell företeelse, men det är inte en enhetlig filmgenre. Craig Hight skriver att mockumentär snarare ska förstås som en diskurs (Hight, 2008, s. 204-205). Andra förstår mockumentärfilmen som en filmform (Lipkin, Paget \& Roscoe, 2006). Bill Nichols ser den snarare som subgenre och placerar den som en del av den reflexiva dokumentärens modus (Nichols, 1991, s. 160).

Genom att skildra fiktiva ämnen och personer med dokumentära konventioner kritiserar man samtidigt föreställningar om dokumentärfilmens påstådda neutralitet. Ofta används formella koder och förväntningar som vanligtvis kopplas till dokumentärfilm för att dekonstruera själva synsättet på dokumentärfilmen som en objektiv och distanserad registrator. Roscoe och Hight menar att mockumentärfilmen klär av dokumentärfilmen dess kulturella status genom att härma dess stilkonventioner och estetik (Roscoe \& Hight, 2001, s. 6). Mockumentären är i sig "latent-reflexiv», eftersom det kan vara svårt att förutse hur publiken kommer att reagera, förstå och analysera enstaka filmer (Roscoe \& Hight, 2001, s. 53).

Som namnet antyder, betyder "mock» att håna eller förlöjliga. Det går att säga att mockumentärfilm är fiktionsfilm, men en sådan förklaring är inte helt tillfredsställande även om den i viss mån är korrekt. Mockumentärfilmen härmar berättartekniska metoder, med tillhörande sanningsanspråk, som dokumentärfilmer använder sig av med avsikten att vilseleda sin publik. Den hamnar i ett hybridfack tillsammans med dokudrama, dramadokumentär och andra subgenrer som på olika sätt korsar det fiktiva med autentiskt filmmaterial. Arkivklipp och scener i en mockumentär kan vara helt autentiska men uppsåtet är att förleda publiken. Mockumentär är alltså en hybrid som nödvändigtvis inte är mer sann än fiktionsfilmen eller mindre sann än en "riktig» dokumentärfilm, utan som sammanblandar dessa aspekter av olika anledningar. Den rör sig mer eller mindre obehindrat mellan föreställningar om vad som är autentiskt, äkta, påhittat och fiktivt. 


\section{4 | SANJIN PEJKOVIĆ}

Mockumentärfilmens funktioner är främst intertextuella och subversiva. Mockumentärfilmer anammar dokumentärfilmsestetik för att skapa fiktiva världar. Deras parodiobjekt är flerfaldiga: dokumentärfilmen som visningsform, dokumentärfilmsutövare, men även kulturella och politiska ikoner. Mockumentärfilm måste vända sig till en publik som känner igen och uppskattar den självreflexiva humorn som är inbäddad i formen. Slutligen, mockumentärfilm provocerar fram frågor kring filmform, inte minst kring sammanblandningen av det fiktiva och det autentiska. Är det etiskt försvarbart att väva en lögn men marknadsföra den som sanning? Om inte mockumentärfilmen leder till en större mediemedvetenhet, är då genren legitim? Man kan också fråga sig vem som bär ansvaret. Är det åskådarens ansvar att urskilja sanning från fiktion eller ligger ansvaret hos filmskaparen?

Mockumentärfilmens beskaffenhet kan enkelt illustreras utifrån René Magrittes målning La trahison des images (Bildernas opålitlighet, 1928-1929) där orden "Ceci n'est pas une pipe» (Det här är inte en pipa) står bredvid målningen av en pipa. En mockumentär kan ha liknande effekt på sin publik, då den ofta ställer en likartad fråga - är detta verkligt? $\AA$ ena sidan är svaret nekande, vilket gäller för alla dokumentärfilmer - det är inte verkligt, det är en representation. Å andra sidan, målningen av pipan och ett filmiskt porträtt som det av det påhittade bandet Spinal Tap (Spinal Tap, Rob Reiner, 1984) är verkliga i den mån de existerar i sin egen ontologiska värld, på samma premisser som exempelvis karaktärer i Star Wars (Stjärnornas krig, George Lucas, 1977).

Idag är linjen mellan det dokumentära och det fiktiva bortsuddad sedan länge. Dokumentärrelaterade program av olika slag som dokusåpor, dramadokumentärer och reality-tv, allt mindre inspelningsutrustning och mobiltelefonkameror, plattformar som Youtube samt sociala nätverk har på olika sätt suddat bort gränser mellan det privata, det offentliga, det kollektiva och officiella narrativ och diskurser.

\section{Mockumentärfilm och historieskrivning}

Rörliga bilder som historiskt källmaterial och som ett historiografiskt framställningssätt ställer oss inför andra utmaningar än det skrivna ordet, som dominerat historieskrivningen under lång tid. Mockumentärens styrka i förhållande till historiografiska framställningar är att den kan skapa tvivel. En film med mockumentära inslag lyckas bäst eller är snarare mest användbar när den lyckas blanda nuet och det förflutna genom falsk framställning så att publiken börjar tvivla på historiskt dittills otvetydiga och cementerade sanningar. Därtill kan formen bidra till att dekonstruera socialpolitiska ställningstaganden som generellt sett omfattar dokumentärfilmens förhållande till historia. Medan dokumentärfilm anses vara objektiv och distanserad när det handlar om skildringar av historiska skeenden hjälper mockumentären till att destabilisera denna uppfattning. Genom att problematisera det som kan anses vara verkligt och sant, kan mockumentärer avslöja hur »historiska sanningar» skapas. 
Hur mycket av historiska filmers historiska återgivning kan vi då tro på? Enligt Robert Rosenstone beror det på vilken film man talar om. Filmers sätt att skildra det förflutna skiljer sig väldigt mycket åt, vilket innebär att vi inte kan tala om historisk film i singular (Rosenstone, 2000, s. 52). Gemensamt är dock det faktum att en film aldrig kan återskapa en historisk händelse så som den en gång hände. Filmer fiktionaliserar, trivialiserar och romantiserar människor och händelser. Filmvetaren Mats Jönsson menar att en viktig omständighet åskådaren bör vara uppmärksam på är att bildflödet har en diskriminerande selektivitet. Det som inte syns i bild måste också vägas in i utvärderingen av mediets funktion som återgivare (Jönsson, 2004, s. 84).

Rörliga bilder, inte minst genom den digitala teknikens utveckling, destabiliserar, kompletterar, öppnar upp, ifrågasätter och på andra sätt ställer frågor om det förflutna. Mockumentären gör detta på ett extra tydligt sätt genom att undergräva den egna berättartekniska beskaffenheten. Mockumentären kan användas till att förutsättningslöst utforska vårt närmande till det förflutna - eller låta det närma sig oss - ur nya och oanade synvinklar. En film är därför filmskaparens egna personliga reflektioner över historien snarare än en spegel som reflekterar det förflutna. Enligt Rosenstone är den viktiga frågan inte huruvida historisk film förmedlar fakta lika bra som skriven historia, utan om vilken typ av historisk värld som varje enskild film konstruerar. Rosenstone vill veta hur denna världen konstrueras, och vilken betydelse den sedan får för publiken (Rosenstone, 2000, s. 52).

\section{Jugoslavien, dess historia och filmutvecklingen}

Området som skulle få heta Jugoslavien har under långa perioder varit ockuperat av mäktiga imperier som dominerat politiskt, ekonomiskt men också kulturellt. Dessutom var området centraliserat och svårstyrt med många upplopp, exempelvis det första och andra serbiska upproret mot Osmanska riket i början på 1800-talet, som följd (Resic, 2006, s. 111-114). Österrike-Ungern ockuperade området 1878. Vissa reformeringsförsök gjordes, och en viss industrialisering började äga rum (Resic, 2006, s. 143-151). Efter första världskriget skapades "Serbernas, Kroaternas och Slovenernas rike». Konflikterna mellan folkslagen växte och 1929 införde kung Alexander kunglig diktatur. Landets tidigare namn byttes ut mot Jugoslavien, "Sydslavien». När kung Alexander dödades 1934 hamnade landet återigen i en stor kris. Den 6 april 1941 började Tyskland bombardera Belgrad och andra världskriget hade börjat även i Jugoslavien. Motståndet var svagt och landets ledning kapitulerade efter några dagar (Pavlowitch, 1988, s. 274-282).

Jugoslavien var inte helt besegrat och en motståndsrörelse organiserades under ledning av Josip Broz Tito. Partisanerna uppträdde som »de sanna jugoslaverna». Alla folkslag deltog i Titos kamp att befria landet från ockupationsmakten (Velikonja, 2003, s. 92; Bougarel, 2003, s. 105; Jović, 2003, s. 160-161). Man lyckades dock inte med att locka Kosovoalbanerna i den omfattningen man hade önskat (Poulton, 2003, s. 127-128). Den serbiske generalen Draža Mihajlovićs förband, Četnici, hade 
som mål att återupprätta det storserbiska riket. För det mesta slogs de inte mot tyskarna utan mot partisanerna och blev ökända för massakrer på andra folkslag. Samtidigt bildades Nezavisna Država Hrvatska (Det Självständiga Kroatien), NDH, under ledning av Ante Pavelić, kroatisk emigrant som återvände efter de tyska attackerna och ledde de extrema kroatiska nationalisterna, Ustaša. NDH var ett satellitland till Nazityskland och under landets existens dödades många serber, judar och romer, men även kroater som inte ville stödja denna fascistiska stat. Efter andra världskriget utnämndes Tito till landets president (Resic, 2006, s. 211-220).

1948 kom en avgörande punkt i jugoslavisk historia som skulle fortsätta prägla landets relationer till öst och väst under det kalla kriget. Den 28 juni uteslöts Jugoslavien ur Kominform, en sammanslutning av europeiska kommuniststater, och det gjorde västmakterna mer benägna att ge Tito ekonomisk hjälp. Orsaken till uteslutningen var bland annat bråk mellan Tito och Stalin, där Stalin hade anklagat Jugoslavien för att vilja vara ett kapitalistiskt land. Några högt uppsatta jugoslaviska politiker hade anklagats för att vara trotskister. När Jugoslavien uteslöts blev det strikt förbjudet att uttrycka sympatier för Sovjetunionen. Stalinsympatisörer skickades till Goli Otok, Den Nakna Ön, där man bland annat genom straffarbete tvingade dem att ändra sina politiska uppfattningar (West, 2009, s. 232-241).

Hotet från Sovjetunionen förstärkte Titos position som landets president, samtidigt som oppositionen försvagades. För att ytterligare avlägsna sig från stalinismen införde man ekonomiska reformer som skilde sig från Sovjetunionens. Till skillnad från ett starkt centraliserat system införde man självförvaltningssystemet. De viktigaste frågorna skulle avgöras lokalt och arbetarna skulle få större inflytande genom att själva välja vilka som skulle representera dem. Ett originellt system bildades $i$ Jugoslavien som icke-officiellt kallades "något emellan». Utrikeshandeln var orienterad mot Västeuropa och USA och detta medförde att Jugoslavien närmade sig väst även kulturellt. Det visade sig senare att självförvaltningssystemet inte fungerade lika bra i praktiken som på pappret. De som bestämde i olika arbetarråd ordnade ofta höga löner och materiella förmåner åt sig själva. Men till skillnad från de flesta kommunistländerna förblev Jugoslavien ett förhållandevis öppet land där folk kunde resa utomlands men också återvända när de önskade. Ofta handlade det om arbetare som inte kunde få jobb och lockades västerut, främst Tyskland, Österrike och Sverige (Lampe, 2003, s. 189-195).

Efter att hotet från Sovjetunionen hade tonats ner började den inre oppositionen höras allt tydligare. Då studentdemonstrationerna spreds över hela Europa protesterade även studenterna i Jugoslavien. I slutet av 1960-talet började också lärare på flera universitet i republiken Kroatien kräva att kroatiskan skulle erkännas som ett eget språk - inte underordnas serbokroatiskan. En del studenter och intellektuella - men långt ifrån alla - började visa nationalistiska tendenser även inom kommunistpartiets lokala organisationer. Men en konflikt fanns inom själva partiet mellan reformerande krafter och makten. Det blev uppenbart för partitoppen att en möjlig kulturell mångfald förr eller senare skulle leda till krav på politisk 
mångfald. En kulturkongress sammankallades 1971 och indikerade en intensifierad ideologisering av konst och kultur.

I politisk mening var 1970-talet i delrepubliken Kroatien betingad av den kroatiska våren 1971 när kroatiska politiker som Savka Dabčević-Kučar, Miko Tripalo och andra försökte reformera partiet i Kroatien (Goldstein, 2003, s. 33). Nästan 400 personer rensades ut från de högsta skikten av partiet. Fortsättningen under tidigt 1970-tal ledde till en partipolitisk utrensning av liberala krafter. De som ville reformera utsattes för medieattacker och efter Titos offentliga kritik lämnade unga politiker, bland andra det serbiska kommunistpartiets ordförande och sekreterare Marko Nikezić och Latinka Perović, sina poster. Liberalernas fall resulterade i att situationen i landet blev mer eller mindre dogmatisk igen. År 1974 presenterades en omarbetad konstitution, som till skillnad från de tidigare hade kraftiga inslag av decentralisering. Förutom republikerna skapades även två självständiga regioner, Vojvodina och Kosovo, som kunde ses som en försvagning av delrepubliken Serbiens roll och inflytande (Jović, 2008, s. 97-103).

Den 4 maj 1980 dog Josip Broz Tito efter en längre tids sjukdom. Efter sig lämnade han ett land som redan var i upplösningstillstånd, men som mer officiellt kollapsade drygt tio år senare. På 1980-talet var samhället i gungning. Efter Titos död kom det fram flera politiska ledare som anspelade på nationalismen hos sina respektive grupperingar. Delrepublikerna hade sina första fria val och krisen förstärktes när flera nationalistledare fick makten. Den växande nationalismen ledde till omfattande konflikter, splittring och öppna krig, och landet upplöstes i början på 1990-talet (Resic, 2006, s. 251-270).

Jugoslaviens upplösning har varit ett omtvistat ämne, i både mediala och akademiska diskurser, och även i Houston, we have a problem!. Ett antal olika förklaringar har under åren framställts som mer eller mindre trovärdiga. Vissa skulle kunna kopplas samman, då en enda förklaringsmodell sällan räcker till. Jag ska här översiktligt presentera ett antal av de mest populära och vanligast förekommande teorierna.

Historisk konflikt. Fokus ligger på historiska orsaker som ligger till grund för konflikter. Historiska konflikter ses varken som ett resultat av evigt hat eller av det genetiska arvet i området. Snarare ses de som en reservoarkälla för olika förklaringsmodeller som används när de passar. Tyngdpunkten ligger oftast på fallerade demokratiseringsprocesser under det första Jugoslavien, det vill säga mellankrigsperioden i landet. Problemet med denna teoribildning är att konflikter under 1990-talet presenteras som förutbestämda och oundvikliga. Konflikten tolkas ibland som en explosion av latent etniskt hat som pyrt under en lång tid och det förklaras inte utförligt varför perioder av välstånd och interetnisk solidaritet inte kunde hindra framväxten av nya konflikter (se bland andra Cohen, 1995; Lampe, 2000; Banac, 2001; Đokić, 2007; Đokić, 2003; Đokić \& Ker-Lindsay, 2011).

Kontextuellt narrativ kring landets kollaps. Nationalism, etnicitet och identitära ideologier är egentligen inte starka anledningar till landets splittring men har använts av politiker och kultureliten för att trigga politiska kriser och har till slut lett till 
upplösningen. Problemet i dessa idéer är att de ignorerar olika dynamiska processer och flexibilitet, och därmed inte lägger vikt vid identitetsprocesser och vikten av etnicitet under 1980- och 1990-talen (se bland andra Glenny, 1992; Magaš, 1993; Denitch, 1994; Woodward, 1995; Little \& Silber, 1996; Gagnon, 2004).

Fugoslavien vissnade bort. Tyngdpunkten ligger på att försöka förklara hur jugoslaverna växte ifrån varandra och hur religioner, media och andra faktorer användes för att konstruera konflikter. Bland annat ses etniska konflikter som omtvistade processer och etnicitet och identitet som någonting som mobiliseras för olika syften. Detta kan ses som problematiskt eftersom inga "varför» kan besvaras. Till exempel: Varför fanns det ingen reell opposition till landets fragmentering? Varför försvarade inte jugoslaverna Jugoslavien? Varför accepterade jugoslaverna andras tilldelade roller på dem, och varför förlorade både Jugoslavien och den jugoslaviska identiteten sin kraft hos medborgare (se bland andra Ramet, 1992, 2002; Perica, 2002; Jović, 2008; Sindbæk, 2012; Hayden, 2013)?

Nationalism och förstörelsen av andra alternativ. Frågorna är fokuserade på maktrelationer, kulturens roll och symbolanvändning. Man försöker hitta svar på både "varför"- och "hur"-alternativ till nationalistiska diskurser kunde försvinna. Ibland kan argumenteringen vara för ytlig och generaliserande i försöken att etablera en dikotomi mellan nationalism/ondska och kosmopolitism/godhet. Samtidigt pekas det också förtjänstfullt på roller som kulturella, politiska och akademiska eliter haft på att mobilisera och förbereda egna etniska grupper på framtida konflikter (se bland andra Wachtel, 1998; Gordy, 1999; Dragović-Soso, 2002, 2008; Čolović, 2000, 2007, 2008).

En del forskare anklagar väst för att ha försökt kontrollera och splittra landet (Johnstone, 2003; Chomsky, 2018) Enligt dessa är stormakternas önskan att söndra landet ett sätt att återta kontrollen i området. Dessa teorier kan användas i revisionistiska syften genom att försvara exempelvis Milošević och hans gärningar. Han blir till en antiimperialistisk symbol, en hjälte som inte gav efter för västmakternas krav.

Även teorier som handlar om urgammalt hat har diskuterats (Kaplan, 1993). Dessa gör ofta gällande att människor på Balkan är alltför temperamentsfulla, att de inte kan styra sina känslor och att det oftast är den huvudsakliga anledningen till mängden krig i området. Denna sydslaviska predisposition var antingen kulturell eller genetisk och leder med jämna mellanrum till brodermord.

\section{Filmproduktion i Jugoslavien efter andra världskriget}

Efter andra världskriget ansåg högt uppsatta politiker att man med bland annat kulturproduktion i allmänhet och av film i synnerhet kunde ena befolkningen i de olika republikerna. På 1940- och 1950-talen lade man grunden till det som senare skulle uppfattas som fenomenet jugoslavisk film. Redan i de första dokumenten som undertecknades av partitoppen 1944 står det tydligt att filmkonsten skulle tjäna till 
att berätta om andra världskriget och kampen mellan nazister och kommunister i Jugoslavien (Ostojić, 1977, s. 40-43). I grunden baserades den jugoslaviska filmproduktionen på nationella centra som producerade olika filmer. Man samarbetade under regimens ideologiska övervakning och i syfte att tvinga fram en känsla av "broderskap och enhet» (Goulding, 2002, s. 7-11). Även själva filmproduktionen bar spår av strategin av att skapa en vidare gemenskap. Slavica (1946) gjordes i Serbien av kroaten Vjekoslav Afrić och kroatiska skådespelare, medan den första kroatiska filmen Detta folk ska leva (Živjeće ovaj narod, 1947) gjordes av Nikola Popović från Belgrad med rollerna tolkade av serbiska skådespelare. Liknande samarbeten, från början gjorda under partiets övervakning, blev allt naturligare och fortsatte även efter landets splittring.

Den jugoslaviska filmens estetik låg i början nära socialistisk realism som dominerade Sovjetunionen. Man skulle klart kunna skilja på bra och dåliga karaktärer, avsluta filmerna på ett optimistiskt sätt och hylla kollektivet framför individualismen. Även om hjälten/hjältinnan dog skulle inte det vara förgäves utan för allas bästa. Deras uppoffring var för landets bästa. Stjärnsystemet förkastades av ideologiska skäl och man försökte skydda sig mot underhållningsfilmer som gjordes i USA (Goulding, 2002, s. 7-9). När Stalin bröt med Tito 1948, ändrades filmpolitiken avsevärt. Propagandan började bespotta den forne vännen och det gjordes uttalanden om att de skadliga influenserna på jugoslavisk film inte nödvändigtvis behövde komma från väst, de kunde lika gärna ha haft sitt ursprung i öst (Raspor, 1950, s. 3). Musikjournalisten Petar Luković skriver också att ett nej till Stalin betydde ett ja till jazzen (Luković, 1989, s. 11). Med andra ord, populärkulturen öppnades upp mot en bredare influens till västvärlden efter uppbrottet med Sovjetunionen. För att försöka avlägsna sig från Sovjetunionen började man införa decentralisering och öppna Jugoslavien mot västvärlden med amerikanska filmer importerade i stor skala (för det komplexa förhållandet Hollywood - Jugoslavien, se Vučetić, 2012, s. 79-162). Nya regissörer ersatte de gamla och nya ämnen togs upp. Man fick vissa möjligheter att ställa obehagliga frågor om andra världskriget och efterföljande händelser. Även partisanfilmen förändrades och fick en mer subjektiv framtoning. Man började gestalta komplicerade känslor och karaktärer som svävade mellan det goda och onda (Goulding, 2002, s. 62-83).

Utmärkande för de nya regissörerna var inte en gemensam stil utan deras kärlek till film och det subjektiva och icke-linjära berättelser. Den nya filmen blev benämningen på ifrågasättande och kritiska filmer vars regissörer egentligen inte var antikommunistiska, utan snarare ville förbättra systemet (Levi, 2007, s. 26-32). Först när dessa regissörer hamnade $i$ onåd hos kritikerkåren och de oförstående partifunktionärerna vände sig vissa mot det kommunistiska partiet och den statliga ideologin. Filmens frigörelse handlar om en viss liberalisering men också om nya politiska och ekonomiska omständigheter. Från ena sidan hade självförvaltningssystemets implementering resulterat $i$ en större decentralisering på filmproduktionsfronten samtidigt som den förbättrade ekonomiska situationen möjliggjorde 
fler produktioner och utvecklade finansieringsplattformar, produktion och distribution. Goulding refererar till den nya filmen som en lös samling filmmakare och filmer som utan att ha ett gemensamt estetiskt perspektiv försökte att öka individuella och kollektiva friheter. Filmen skulle engageras och användas i samtal kring kontemporära teman. Dessa skulle innehålla kritik mot mörka, ironiska, alienerade delar av individuella, kollektiva och politiska diskurser (Goulding, 2002, xii). Man kan förstå den nya filmen som en negationsfilm. Den revolterar mot den alldagliga och genomsnittliga filmen och friheten används som en negation. Den nya filmen kan ses som en motsats till den gamla filmen som andas dogmatisk ideologisering.

Flera filmer förbjöds. Vissa regissörer sattes i fängelse som Lazar Stojanović för sin film Plastjesus (Plastični Isus, 1971). Andra blev persona non grata och tvungna att flytta utomlands, som Dušan Makavejev för WR: Kroppens mysterier (WR: Misterije organizma, 1971). Det som började som en fräsch våg av liberala krafter avslutades på ett - för denna tid ganska vanligt sätt - med våld och hot. Jugoslavien sågs i väst under denna period som ett land med mycket frihet och lite demokrati (Crnobrnja, 1994, s. 76).

Efter att kommunistpartiet hade fått ordning på filmproduktionen i Jugoslavien i början på 1970-talet, koncentrerade man sig på lättare filmer som undvek baksidor av den socialistiska samhällsapparaten och förstärkte "den jugoslaviska känslan» inte individualismen. Stora spektakel, lätta komedier och filmer som på intet sätt utmanade det dåvarande läget i Jugoslavien präglade åren mellan 1973 och 1977. I stället för att gå på bio valde man att stanna hemma och titta på tv, och det blev en av orsakerna till att filmindustrin hamnade i en djup svacka (Goulding, 2002, s. 143). Det behövdes samma sak som i början på 1960-talet - nya regissörer som kunde utmana publiken. Flera hade fått sin utbildning vid FAMU i Tjeckoslovakien och kallades i medier för Pragskolan (Praška škola): Srđan Karanović, Rajko Grlić, Goran Paskaljević, Goran Marković och Lordan Zafranović. Men det var inte bara Pragskolan som dominerade den jugoslaviska filmindustrin. Här fanns också Emir Kusturica, som också hade utbildat sig vid FAMU men tillhörde en yngre generation, Slobodan Šijan, Ademir Kenović och Miloš Radivojević, som blev populära både i Jugoslavien och i utlandet.

Efter Titos bortgång kunde kontroversiella ämnen diskuteras mer öppet. Avstaliniseringsprocesser efter 1948 men även samtida problem som landets dåliga ekonomi och höga arbetslöshet började förekomma i allt högre grad. Efter landets splittring tog det ett tag innan nationella filmindustrier konsoliderades. Filmproduktionen skulle förvandlas och underordnas ett nytt ekonomiskt system. Det ledde bland annat till att regissörer kunde ha svårt att hitta finanser till sina projekt. I och med etableringen av marknadsekonomi blev plötsligt konkurrens och profit viktiga parametrar att tänka på i filmproduktionsyrket.

Trots den nationalistiska uppväckelsen och landets splittring fortsatte vissa filmarbetare att samarbeta även under och efter de krig som hade brutit ut under 1990-talet. Bundna av gamla vänskapsband, på jakt efter de perfekta skådespelarna, 
av nostalgiska eller distributionsmässiga skäl, återupptog de samarbeten (Goulding, 2002, s. 186, 232).

Många partier som vann de första demokratiska valen tog avstånd från allt som hade med det socialistiska Jugoslavien att göra. I Kroatien togs gamla symboler bort och ersattes med nationalistiska motiv. Dessa hade visserligen använts och hade förbjudits efter andra världskriget. Nu infördes de återigen för att betona den nationella frigörelsen från Jugoslavien. Ett »officiellt» åsiktsbyte ägde återigen rum efter Franjo Tuđmans död och nationalismen skulle tonas ner. Det politiska klimatet ändrades något och möjliggjorde att filmare fick tillfälle att kritiskt skildra Tuđmans regim. På samma sätt liberaliserades det kulturella klimatet i Serbien något efter att Slobodan Milošević fick se sig besegrad efter den femte oktober år 2000.

Samproduktioner, filmfestivalernas samarbete, likheter i språk, det kulturella bagaget, historien gör att filmer från regionen fortfarande kan attrahera publiker i de andra forna delrepubliker, och därför bör områdets filmer analyseras inte enbart utifrån nationell filmforskning. Dikotomin präglar inte enbart det filmteoretiska fältet utan även andra områden, och bottnar i ideologiska meningsskiljaktigheter om hur man ska tolka det förflutna. Jugoslavisk filmhistoria måste existera på samma sätt som Weimarrepublikens film och sovjetisk film, som en samling filmer som producerats i ett särskilt historiskt sammanhang.

Under 2000-talet har filmkritiken och teorin utvecklats åt två håll. Den ena linjen betonar utvecklingen av den nationella filmproduktionen, där även jugoslavisk film inkorporeras i en nations kulturbygge. Den andra linjen är mer benägen att prata om postjugoslaviska filmkulturer.

Mira och Antonin Liehms inflytelserika filmhistoriska studie The Most Important Art: Soviet and East European Film After 1945 skulle efter murens fall bidra till att skapa ett paradigm för tolkning av filmens roll i socialismens Östeuropa (Liehm \& Liehm, 1977). Enligt paret Liehm jobbade man antingen inom systemet och skapade partipropaganda, eller så var man dissident. Studien var intressant och tankeväckande när den kom men den överensstämde inte med synen och debatter på film som fördes av teoretiker, kritiker och filmverksamma i Öst- och Centraleuropa och inte minst i det forna Jugoslavien. I sin biografi bifogar regissören Aleksandar Petrović kopior på protokoll som fördes under vissa filmarbetarmöten, där det kan ses att filmproduktionen inte var så rigid som det framställs i filmhistoriska omskrivningar (Petrović, 1971). Tvärtom, livliga och intressanta diskussioner fördes, ofta med en god insyn i den politiska filosofins spår. Regissörer som bland andra Dušan Makavejev, Živojin Pavlović, Aleksandar Petrović kände till hur den aktuella filmsituationen i världen såg ut när de diskuterade den jugoslaviska filmens tillstånd. Petrovićs protokoll och Živojin Pavlovićs minnesanteckningar vittnar om att regissörer vars filmer ansågs vara problematiska var inga dissidenter. Tvärtom var de ofta idealister som ville förbättra det samhälle de levde i. Några var medlemmar i partiet, andra inte. Det som drev dem i många fall var inte en kritik av kommunismen i sig, utan av utnyttjandet av ideologin för egen profit (Petrović, 1971; Pavlović, 1996). 
Den analytiska modell som paret Liehm satt upp har fortsatt dominera synen på filmskapande under kommunismen även efter murens och kommunismens fall. Användningen av "artisten kontra regimen»-dikotomin skulle resultera i att postjugoslaviska filmkritiker och historiker skildrade filmhistorien i landet som en del av ett totalitärt paradigm (se bland många andra: Škrabalo, 1998; Munitić, 1999; Ognjanović \& Velisavljević, 2008; Tirnanić, 2008; Pajkić, 2009; De Cuir, 2011). Processen skedde i alla forna delrepubliker. Enligt dessa kritiker och forskare var jugoslavisk filmindustri främst en arena där den totalitära regimen brutalt utnyttjade den absoluta repressiva makten för att skydda sina dogmer.

Omskrivningen av historien omfattar alla kulturområden och sker i samförstånd med officiellt utsuddande av det man uppfattar som det gemensamma förflutna, i sin tur också en konstruktion då det socialistiska Jugoslavien behövde myter för att överleva. Det faktum att Jugoslaviens nya regering väldigt ofta påpekade att man inte behövde hjälp från allierade för att befria landet under andra världskriget gjorde att en nationell stolthet växte fram. Detta var naturligtvis inte helt sanningsenligt, eftersom stora sovjetiska trupper hjälpte till att befria norra Serbien och även tog sig in till Belgrad tillsammans med partisanstyrkorna. Idén om ett enat Jugoslavien fick dock fäste och andra världskriget spelade en stor roll i identitetsskapandet. Därför speglade de flesta filmer sammanhållningen och de heroiska insatserna under kriget.

Benedict Anderson pratar om skapandet av den gemensamma nationella identiteten och kallar detta för den föreställda gemenskapen (Anderson, 1993). Anderson försöker hitta hur nationalismen, som egentligen är en naturlig fortsättning av den nationella medvetenheten, skapats genom tider och hävdar att "nationlighet som nationalism är kulturella artefakter av ett speciellt slag»(Anderson, 1993, s. 19). Nationalismen ersätter i mångt och mycket religionens och det dynastiska rikets roll i skapandet av kollektivet kring en idé, en sak eller tecken som kan förmedla ett budskap. Anderson menar också att nationalism, till skillnad från ideologier som marxism, tar upp människans sökande efter svar, exempelvis kring döden, på liknande sätt som religioner tidigare gjorde. Därför finns det symboler som hedrar de döda som offrat sina liv för ett högre mål, exempelvis den okände soldatens grav (Anderson, 1993, s. 23-25). Filmen förstärkte nationens föreställda illusioner genom mäktiga episka berättelser om partisanernas kamp mot större och starkare makter.

Unga länder som Jugoslavien saknade myter och hjältar som skulle förstärka nationalitetskänslan hos medborgarna. Exempelvis hade Slovenien aldrig ens ingått i samma land som Makedonien före serbernas, kroaternas och slovenernas rike. Det som kunde förena dessa två delrepubliker var att de stred på samma sida mot ockupanterna. Därför blev partisanhjälten en del av den nya mytbildningen som samtidigt utvecklades inom musik, litteratur och film. Hjältarna representerade hela landets uppoffring och kamp och känslorna i filmerna pendlade mellan två lägen - kärleken till sitt land och hatet mot fienden. Partisanfilmen hade som syfte att hålla kriget aktuellt i tittarnas minne, och genom att ständigt visa hotet utifrån ville man öka "jugoslavismen» bland befolkningen. Befolkningens engagemang kring 
krigsfilmer var stort i Jugoslavien. Det finns flera förklaringar till detta. Filmerna är dynamiska, tar upp landets historia och moraliska värderingar och hyllar offrandet för högre ändamål. Dessutom var viljan ovanifrån att propagera och indoktrinera en av huvudfaktorerna till att det spelades in så många krigsfilmer.

\section{Houston, We Have a Problem!}

Houston, We Have a Problem! handlar om det forna Jugoslaviens rymdprogram som Josip Broz Tito inser värdet av under det kalla kriget. Under en period då Sovjetunionen leder i kriget om rymden, säljer Tito programmet till USA och president Kennedy för 2,5 miljarder dollar. Det visar sig dock att jugoslaverna egentligen inte hade något att sälja, deras rymdprogram är helt obrukbart. Utbetalningen förvandlas till ett lån, vilket tvingar Jugoslavien till en svår ekonomisk kris. Tito dör och med en mer eller mindre direkt inblandning från amerikaner dör Jugoslavien med honom. CIA skapar nämligen en plan för hur landet ska splittras och vad USA bör göra för att öka splittringen och på så sätt få tillbaka sina investerade pengar.

Förutom kollektiva konsekvenser handlar filmen även om Ivan Pavić, en av 26 ingenjörer som transporterats till USA för att hjälpa till med utvecklingen av rymdprogrammet. Pavić fick inte ens ta avsked från sin familj, har varit bosatt $i$ USA i 50 år och är nu tillbaka för att träffa sin dotter för första gången. Skildringen av Pavićs liv används som en motvikt till det kollektiva narrativet som baseras på officiellt arkivmaterial av Titos USA-besök. Pavićs berättelse är mer nyanserad och individualiserad i jämförelse med resten av filmen. Han framställs som ett litet men viktigt kugghjul, ett offer för politiska spel som inte tar hänsyn till individuella öden. Även den slovenske filosofen Slavoj Žižek intervjuas och kommenterar Jugoslaviens rymdprogram, konspirationsteorier, föreställda motsatsförhållanden mellan sanning och lögn, det forna Jugoslavien men också själva filmen.

Regissören Žiga Virc menar att filmens huvudsyfte har varit att ifrågasätta konspirationsteorier och olika sanningskoncept. Sanning och fiktion är, enligt Virc, inbäddade i varandra och tillsammans konstruerar de en politisk thriller som öppnar upp sig mot publiken och kräver en respons, en aktiv analys (Barone, 2016). Efter de första festivalvisningarna visade det sig att kritikens och publikens fokus ofta låg på frågor som rörde autenticitet och sanning. Vissa delar av publiken på Tribeca-filmfestivalen, där filmen hade sin premiär, kände sig besvikna och lurade eftersom de under filmens gång trodde på berättelsen (Pond, 2016). Under efterföljande samtal vägrade Virc att berätta vad som var sant och påhittat. Det Virc tillstod var att han ville göra en symbolisk berättelse om Jugoslaviens uppgång och fall (Pond, 2016). Virc skulle senare referera till sin film som dokufiktion, menad att vara en audiovisuell berättelse om Jugoslaviens uppgång och fall (Dalton, 2016).

Houston, We Have a Problem! visar på problemet med att tro på att dokumentärfilmer som baseras på verkliga arkivklipp är allvetande och objektiva. Å ena sidan är varje klipp sanningsenligt, varje händelse har inträffat framför kameran. 
Sammansättningen av alla händelser är dock medvetet förfalskad. Även Žižeks metatextuella kommentarer - och scenen där han konfronterar sitt yngre jag - används för att problematisera Vircs olika påståenden men också de expertroller som inte bara förekommer i dokumentärfilm, utan används som ett "bevis» på att något är korrekt.

Jugoslaviens historia under 1960-talet passar på ett intressant sätt Vircs kreativa audiovisuella historieskrivning. Landets närmande till väst under 1940- och 1950talen blev ännu tydligare, samtidigt som Jugoslavien valde en så kallad tredje väg, en alliansfrihet som landets ledning utnyttjade vad gäller vapenförsäljning till andra alliansfria länder. Jugoslaviens alliansfrihet och stabilitet var av strategisk vikt för västvärlden, vilket ledde till stor ekonomisk hjälp under perioden. Historikern Radina Vučetić kallar Jugoslaviens icke-officiella ideologiska hållning för Coca Cola-socialism, där hängivenheten finns för både Marx och västerländsk livsstil (se Vučetić, 2012).

Samtidigt som filmen problematiserar digitala medier och sanningsrelativism utifrån det forna Jugoslavien, är den också fast förankrad i konspirationsteoriernas värld. Den antyder att mordet på president Kennedy har att göra med rymdutvecklingsprogrammet. Förhållandet mellan Tito och Kennedy utvecklas till det sämre efter försäljningen av rymdprogrammet. Tito åker till USA och överlever ett attentat. Vi får höra ett telefonsamtal mellan Kennedy och Tito. Tonen är tafatt och stämningen generad. Kennedy undrar hur Tito mår, han svarar att allting är bra och bjuder Kennedy att komma till Jugoslavien, vilket besvaras med ett nervöst skratt. Det krystade samtalet leder oss till nästa scen, vilket är attentatet på Kennedy. När filmen tar upp frågan om mordet på Kennedy har att göra med Jugoslavien och rymdprogrammet, tittar historikern Roger McMillan, experten som besvarar alla frågor om rymdprogrammet, in i kameran och säger att han inte vill kommentera.

Rymdresan till månen och attentatet på Kennedy, två av de mest konspiratoriska ämnena i USA under 1900-talet, används i Houston, We Have a Problem! som intertextuella blinkningar i konspirationsteoretiska kontexter. Titos besök, det misslyckade attentatet på honom och samtalet med Kennedy är händelser som inträffat på riktigt. De visar på ett sätt att förhållandet mellan det officiella USA och Jugoslavien låg på en nästan vänskaplig nivå. Det misslyckade attentatet på Tito genomfördes av serbiska extremgrupper boende i USA, en nationalistisk diaspora som såg sin chans att göra upp med sin fiende. Filmen inkorporerar alla händelser till en övergripande konspirationsteori som på det viset tillåter berättelsen att växa till enorma proportioner. Varenda arkiverat och filmat evenemang blir till ett kugghjul, en pusselbit i en allomfattande konspiration. Berättarrösten blir till den bärande förklararen, den som syr ihop alla disparata händelser till en unison historia. Medan arkivklipp visar Tito på besök i Marocko, förklarar berättarrösten att statsbesöket bara var en ursäkt. Den riktiga anledningen var att Tito behövde smuggla ut rymdprogrammets delar via marockanska farvatten så att amerikanerna enklare skulle kunna frakta dem vidare till USA.

Dittills aldrig tidigare visade klipp, som exempelvis Tito i Speedo-badbyxor och intervjuer kring hans utländska besök ger en del intressanta representationer som rör sig mellan det privata och det offentliga. Andra klipp ingår i en än mer bisarr 
kontextualisering som berättar om jugoslaviska försök att lansera egna raketer i rymden. Till skillnad från apor, råttor och hundar som skickades upp i rymden med jämna mellanrum, visas det i Houston, We Have a Problem! hur jugoslaverna skickade upp grisar. Efter att den första raketen störtar överlever grisen mirakulöst. Även om den överlever ett fall från stratosfären kan den inte undgå sitt öde. I efterföljande klipp antyds att grisen äts upp av amerikanska astronauter som delar den olycklige rymdresenären med sina jugoslaviska kollegor. Klippet med amerikanska gäster är autentiskt, då besättningen från Apollo 15-teamet besökte Jugoslavien och den slovenska sjön Bled 1972.

Konspirationsteorin eskalerar och blir till ett ironiskt eko av redan bekanta teorier om västvärldens, och i synnerhet USA:s, inblandning i Jugoslaviens nedmontering. Som ett "bevis» spelas Richard Nixons samtal med en medarbetare upp. Nixon säger sig vara beredd att bomba "those Yugoslav bastards». Ljudklippet är delvis förfalskat eftersom ordet "Yugoslav» lagts till i konversationen som i övrigt handlar om Vietnam. I bild syns ett dokument som "bevisar» planen för landets splittring som CIA utarbetat. I själva verket står det att USA kommer att stötta Jugoslavien som går igenom en svår ekonomisk kris eftersom landet är en viktig stabilitetsfaktor i regionen, då det står mellan öst och väst. Den allomfattande konspirationsteorin avslutas med landets sönderfall. Efter att Jugoslavien försökt betala tillbaka en del av skulden genom dåliga exportvaror, som bilen Yugo, som inte riktigt fungerade på den amerikanska marknaden, blev den ekonomiska pressen alltför svår att överbrygga.

Filmens mytiska värld baseras dock på en del fakta. De jugoslaviska rymdexperimenten baserades, enligt filmen, på den slovenskfödde officeren i den österrikiska armén, Hermann Potočnik, också känd under pseudonymen Herman Noordung, vars bok DAS PROBLEM DER BEFAHRUNG DES WELTRAUMS. DER RAKETEN$M O T O R$ publicerades 1929. I boken läggs det fram olika problem som människan måste överbrygga för att kunna resa i yttre rymden. Potočniks bok är autentisk. Överlag var intresset för utforskning av rymden och i senare skede rymdkapplöpningen väldigt närvarande $\mathrm{i}$ jugoslavisk media (för en genomgång av jugoslavernas intresse för det kalla krigets rymdkapplöpning, se Vučetić, 2011). Filmen igenom lyckas man skickligt väva in fabricerade detaljer med de riktiga. Den underjordiska och nu övergivna flygbasen Objekt 505 existerade också vid den kroatisk-bosniska gränsen. I filmen används den som en Area 51-liknande plats. Där experimenterade man med flygförsöken enligt regissören. Platsen är nu övergiven och vittnar om en svunnen tid. Det förflutna och det nuvarande kontrasteras därmed filmen igenom. Bilder av Titos en gång i tiden magnifika skepp Galeb klipps ihop med bilder av skeppet såsom det ser ut idag. Skeppet framstår som en förstörd ruin, liksom idén om Jugoslavien.

\section{Sanningsenliga konspirationer?}

Houston, We Have a Problem! är en hybridfilm sammansatt av arkivmaterial och en påhittad berättelse. Tillsammans skapar de ett frestande "tänk om» som ofta utgör 
den viktigaste ingrediensen i en konspirationsteori. Ett alternativt narrativ kan även tjäna som en melankolisk betraktelse över det förflutna som kan upplevas med hjälp av audiovisuella minnen.

En av förklaringarna till varför vissa mockumentärfilmer lockar större publik och skapar kontroverser kan vara att deras påhittade innehåll fungerar på en autentisk nivå. Carl Plantinga skriver, "In general, documentary refers to the actual world by taking an assertive stance toward its projected world. With fiction a fictive stance is taken, and the state of affairs presented is not asserted to be true» (Plantinga, 1987, s. 49). Även om Plantinga enbart diskuterar den dokumentära filmen och inte dess parodierande kusin, finns det ändå likheter i hur vi tittar på och analyserar mockumentärfilmer. Den värld som projiceras i en mockumentärfilm både existerar och inte existerar. Exempelvis är de arkivklipp som finns i Houston, We Have a Problem! riktiga, de är filmade under Josip Broz Titos besök i USA. Å andra sidan existerar inte just det temat som målas upp som ett fokus för filmen, rymdprogrammet. Mockumentärer har alltså en fascinerande möjlighet att träda ut och in i verkliga och påhittade världar, vilket ger en känsla av både autenticitet och fiktion.

Filmen mystifierar en redan enigmatisk och motsägelsefull historia om ett land med ett brokigt förflutet. Det idiosynkratiskt socialistiska, multietniska och halvkapitalistiska landets existens fortsätter att gäcka dess forna invånare men också forskare som är intresserade av att kartlägga olika anledningar till landets kollaps. Det medvetna användandet av lögner och fabrikationer visar på att Virc är intresserad av att fördjupa frågeställningarna kring landets sönderfall. Kanske är landets historia och historieskrivning så pass omöjliga att reda ut, baserat på olikartade ideologiska ställningstaganden, att det ibland behövs rena lögner för att komma närmare sanningen?

Den fiktiva historieskrivningen kan erbjuda en vidare distansering från olika politiserade följder kring landets existens. Att röra om i redan grumliga vatten kring Jugoslaviens existens är inte att relativisera historien utan det handlar snarare om att belysa en komplexitet rörande audiovisuella praktiker och historieskrivning. Genom att erbjuda nya tolkningar av redan existerade bilder medvetandegör filmen sin publik om en viss svårighet - om inte en omöjlighet - $i$ att hitta ett rätt svar kring alla frågor som rör landets sönderfall. Det kan vara en av förklaringarna till varför det gått bra för den i regionen och utanför. Den har kunnat erbjuda hysteriska förklaringar som samtidigt inte hotar de nationalistiska, nostalgiska och/eller andra narrativ, samtidigt som den internationellt varit bred och generell så att den kunnat attrahera publik. Men eftersom den inte erbjuder några svar och är tvetydig i sin syn på det förflutna, "tvingar» den tittaren att själv ta ställning till och leta fram den svårupptäckta sömmen mellan historiska fakta och fiktion. En fara ligger därmed i att inte alla förstår filmens premisser.

Filmens producent, Boštjan Virc, berättar i en intervju hur förbluffande det var att upptäcka att det fanns delar av publiken som inte ifrågasatte filmen utan tog den för given. Han fascinerades av det faktum att en liten filmproduktion, utan stora pengar inblandade, kunde få människor att tro på illusioner och kontrasterar filmen 
med stora nyhetsproduktioner som manipuleras av regeringar, länder och företag där inget tyder på att något är förfalskat. Virc slår fast att "Seeing is believing! Even if what you're offered is a complete fake! For me, it's quite scary» (Robinson, 2016).

Regissören anser sig inte vara en konspirationsteoretiker, bara en filmmakare som gjort ett verk som ifrågasätter konspirationsteorier men också det som anses vara en generell sanning. Filmen sammanblandar verklighet och fiktion och skapar en politisk thriller där publiken måste orientera sig för att hitta det som är sant och det som inte är det (Barone, 2016). Virc är alltså inte en relativist. Han påstår inte att det inte existerar en faktabaserad sanning, men för att kunna hitta till den måste man vara ytterst kritisk till medierade framställningar av olika sanningar, menar han (Robinson, 2016).

Tito blir till en filmkaraktär, en skådespelare vars porträtt inte riktigt motsvaras av de andra dokumentärerna om och kring honom. Istället för en heroisk eller skurkaktig politiker som porträtteras med hjälp av välkända bilder blir han till en roll av sig själv. Hans beteende klipps ihop så det passar den dramatiserade berättelsen och han blir till en av filmens mer komplext skildrade karaktärer.

En annan person som blir till både en fiktiv och verklig karaktär är filosofen Slavoj Žižek. Under filmens gång förklarar han ett antal nedslag rörande inte minst konspirationsteorier. Dock visas det i slutet på filmen ett klipp där en yngre Žižek medverkar och pratar om nödvändiga liberaliseringar som Jugoslavien måste gå igenom. Dissidenten Žižek kräver under 1980-talet en större demokratisering, något som den nuvarande Žižek uppmärksamt lyssnar på. Metainslag sammanblandas ytterligare när en före detta officer i den jugoslaviska armén säger sig ha avlyssnat Žižek samt att den hemliga polisen länge funderat kring hur de skulle stoppa hans tal och offentliga framträdanden då han ansågs vara för farlig för systemet.

Slavoj Žižek har under filmens gång två till synes olikartade resonemang kring konspirationsteorier. Med det första menar han att mindre intelligenta människor faller för konspirationsteorier eftersom de reducerar och förenklar komplexa situationer till förståelighet. Žižek komplicerar senare denna reducering i filmen: »Paradoxically, one of the ways to hide the truth is to present it as a conspiracy theory, expecting that, as such, no one will believe it.» Konspirationsteorin blir här använd i ett konspiratoriskt sammanhang. Skapas konspirationsteorier underifrån, som ett sätt att visa missnöjet med eliternas förklaring, eller fabriceras de ovanifrån, av de samma eliter, för att de vill dölja just det de anklagas för?

Vircs film kan ses som en symbolisk gestaltning av det jugoslaviska moderniseringsprojektet under Tito, ett projekt som rättfärdigade olikartade former av terror. Genom att skissa fram en berättelse om ett fiktivt rymdprogram, pratar Virc om födelsen och försvinnandet av den jugoslaviska moderniseringen, ett projekt som hade kunnat resultera i välstånd men som slutade i blod. Genom att sälja projektet till USA gav Tito och Jugoslavien upp sin egen politik. Landet och ledningen gav upp den symboliska vägen som påbörjades under andra världskriget och som blev färdigformad under efterkrigstiden. Genom att ge upp vissa ideal blev landet offrat till 
både utländska krafter som inte var nöjda med dess ekonomiska lurendrejeripolitik, och inifrån då en idé ersattes av flera kontradiktoriska. Genom att samtidigt vara en melankolisk meditation över ett land som inte längre finns och en ironiserande och tekniskt välgjord fiktion, kan filmen läsas som en kritik gentemot utländska makters inblandning i jugoslavisk inrikespolitik. Dock är inte utländska maktfaktorer de enda. Även Žižek ifrågasätts och kan ses som en docka som tjänat andras intressen. Genom att spela upp gamla klipp där Žižek efterlyser skepsis gentemot kommunism och ett icke-liberalt system i landet, kan man se den resa som många dissidenter gjort efter att landet splittrats. De är nu i en position där de längtar tillbaka till vissa delar av det gamla systemet och målar upp det förstörda landet som en i grunden human idé.

\section{Mottagande}

En del kritiker applåderade medan vissa fördömde filmens subjektivitet. Det tyder på att vissa kritiker i någon mån trodde på det fiktiva materialet och valde att tolka det bokstavligt trots det påhittade temat. Filmkritiker från regionen såg filmen som billig antijugoslavisk propaganda. Damir Radić, en av Kroatiens mest kända filmkritiker, skriver att huvudfelet i filmen rör själva det fiktiva temat som leder till en riktig händelse, i detta fall Jugoslaviens sönderfall. För att etablera kopplingen måste man enligt honom falsifiera historiska fakta. Ett exempel ärYugos export till USA, något som i verkligheten hände efter Titos död men som i filmen placeras under 1970talet då Tito fortfarande levde. Enligt Radić är dessa förfalskningar kontraproduktiva eftersom många fortfarande minns egna liv och händelser ur landets historia. De kommer att känna igen lögner. Ett annat stort fel är att skratta åt jugoslavisk teknologi genom Yugo och rymdprogrammet. Ur dagens eländiga perspektiv framstår den jugoslaviska industrin som oerhört utvecklad. Jugoslaviska företag arbetade globalt, menar Radić, och att skratta åt dem idag är att missrikta kritiken. Han avslutar sin text genom att peka på att Houston, We Have a Problem! på slutet försöker göra upp med Tito och hans arv. Det fungerar inte genremässigt väl och görs på ett banalt sätt (Radić, 2016).

Den slovenske filmkritikern Marcel Štefančič Jr. skriver att filmen driver med jugonostalgiker för deras tro på att Jugoslavienprojektet var speciellt och att Tito var en viktig historisk person. Samtidigt skojar filmen med människor som anser att socialismen inte kan fungera om den inte finansieras i hemlighet av kapitalistiska länder (Charney, 2016). Marko Stojiljković från Kroatien läser in teorier om västs intresse i att splittra Jugoslavien (Stojiliković, 2016) medan den serbiske filmkritikern Dimitrije Vojnov hyllar filmen eftersom den erbjuder en balanserad och intelligent syn på Jugoslaviens sönderfall trots att svaret erbjuds genom en "busig» form, där en fiktionaliserad berättelse ramas in i en dokumentär (Vojnov, 2016).

Eftersom Vojnov texten igenom gör en skarp och klar distinktion mellan dokumentär- och spelfilmsväsen, kan man anta att den balanserade bilden av Jugoslaviens sönderfall - att det blivit till västmakternas offer - avspeglas i Vojnovs egna 
föreställningar. Den kroatiske filmkritikern Nenad Polimac stör sig dock på filmens falska kronologi (Polimac, 2016). Olika historiska händelser sammanblandas vilket enligt Polimac förstör upplevelsen. Frågan är om filmen hade varit mer sanningsenlig om kronologin hade stämt bättre. Kronologin i Houston, We Have a Problem! skapar inte nödvändigtvis lögner, snarare kontrafaktiska historier med olika "tänk om»-alternativ. Därför framstår det som något paradoxalt att läsa dessa filmrecensioner. Det avslöjar två saker som regionala filmkritiker inte verkar vara immuna mot. Antingen är de inte helt medvetna om mockumentärfilmens spelregler, eller så är de färgade av en ideologiserad syn på landet, vilket även avspeglas i filmkritiken.

Balkan ses som en paradigmatisk plats för paradoxala händelser där ingenting är vad det verkar vara. Rymdprogrammet, resor, Tito, Ivan Pavićs liv, förklaringar till Jugoslaviens sönderfall, Žižek och hans olikartade resonemang. Balkan fungerar som ett symboliskt område där människor bedyrar sin hederlighet samtidigt som de utan skrupler fortsätter att lura varandra. Filmen gör upp med fornjugoslavisk mytologi och mytomani. Inget är som det till synes verkar vara och det måste betyda att inte heller filmens tes håller. En fråga uppstår dock. Vad är Vircs ansvar för filmen, för handlingen, temat, svaren som inte erbjuds? Var står han och resten av filmskaparna? Eftersom Jugoslaviens sönderfall diskuteras på slutet kan det vara intressant att analysera vilka som omnämns och vilka som inte gör det.

Inte ett ord eller en bild ägnas åt inhemska kommunistiska politiker som gått över till nationalistiska alternativ och därmed slitit sönder ett land som de själva varit med om att bygga upp. Och ingenstans nämns det jugoslaviska kollektivets ansvar. I ett montageklipp visas sörjande massor som gråter efter Titos död. Men massorna, vanliga människor som inte är direkt inblandade i landets modernisering, är för det mesta osynliga. Därför kan det framstå som att Radić och andra kan ha rätt när de anklagar Houston, We Have a Problem! för en viss revisionism (Stojiljković, 2016). Žižek är den som "friar» filmen, som istället för att liera sig med vilken teori som helst snarare avlägsnar sig från dem. Žižeks roll är att påvisa att varje teori kan göras funktionell och antas vara verklig. Det betyder inte att den är det, men med hjälp av arkivklipp och ideologiserad historieskrivning kan rykten, påståenden och lösa fragment fogas samman till en alternativ historieskrivning.

"Even if it didn't happen, it's true", säger Žižek i slutet. Det kan ses som en sammanfattning av filmen, för mockumentärformen, konspirationsteorier i stort men också olika "förklaringar» till hur och varför Jugoslavien splittrades. Denna absurda idé gäller lika väl som alla andra, verkar Žižek mena. Främst kan Žižeks uttalande appliceras på att filmen på ett kreativt sätt avmystifierar de rörliga bildernas "makt» att kunna förklara ett visst historiskt skeende. Genom att så tydligt manipulera ett existerande arkivmaterial gör sig filmen inte medskyldig till ytterligare en konspirationsteori. Istället klär den av andra filmer med konspirationsteorier som också återanvänder arkivklipp och avkontextualiserar dem till oigenkännlighet. För att hitta fram till djupare sanningar måste man luras, är något som både Houston, We Have a Problem! och Žižek hävdar. 


\section{Litteraturlista}

Anderson, B. (1993). Den föreställda gemenskapen: Reflexioner kring nationalismens ursprung och spridning. Göteborg: Daidalos.

Banac, I. (2001). Raspad Fugoslavije. Zagreb: Durieux.

Barone, M. (2016, 28. mars). Conspiracies and Cold War intrigue drive the viewpoints premiere Houston, we have a problem!. Tribeca Film Festival. Hämtat 06. november 2020 från https://tribecafilm.com/news/ interview-houston-we-have-a-problem-documentary-ziga-virc-tribeca-film-festival

Barry, B. (2012, 27. januari). What do you make of the "Houston, we have a problem" film claiming that a secret Yugoslavian space program was the source of American success in the space race? Smithsonian National Air and Space Museum. Hämtat 06. november 2020 från https://airandspace.si.edu/stories/ editorial/what-do-you-make-houston-we-have-problem-film-claiming-secret-yugoslavian-space

Bougarel, X. (2003). Bosnian Muslims and the Yugoslav idea. I D. Djokić (Red.), Yugoslavism: Histories of a failed idea, 1918-1992 (s. 100-14). London: C. Hurst \& Co. Publishers.

Bradbury, P. (2012, 10. januari). Did Yugoslav space technology sold by Tito put America in space? Digital Fournal. Hämtat 06. november 2020 från http://www.digitaljournal.com/article/317682

Charney, N. (2016, 20. juni). Did the Yugoslavs help put Apollo 11 on the moon? Observer.

Chomsky, N. (2018). Yugoslavia: Peace, war, and dissolution. Oakland: PM Press.

Cohen, L. J. (1995). Broken bonds:Yugoslavia's disintegration and Balkan politics in transition. NewYork: Routledge.

Čolović, I. (2000). Politika simbola: Ogledi o političkoj antropologïi. Beograd: XX vek.

Čolović, I. (2007). Balkan - teror kulture: Ogledi o političkoj antropologiji 2. Beograd: XX vek.

Čolović, I. (2008). Bordel ratnika: Folklor, politika i rat. Beograd: XX vek.

Crnobrnja, M. (1994). TheYugoslav drama. Montreal: McGill-Queen's University Press.

Dalton, S. (2016, 12. juli). Houston, we have a problem! Hollywood reporter.

De Cuir, G. (2011). Fugoslovenski crni talas. Beograd: Filmski centar Srbije.

Denitch, B. (1994). Ethnic nationalism: The tragic death of Yugoslavia. Minneapolis: University of Minnesota Press.

De Siefe, E. (2007). This is spinal tap. London: Wallflower Press.

Djokić, D. (Red.) (2003). Yugoslavism: Histories of a failed idea, 1918-1992. London: C. Hurst \& Co. Publishers.

Djokić, D. (2007). Elusive compromise: A history of interwar Yugoslavia. New York: Columbia University Press.

Djokić, D \& Ker-Lindsay J. (Red.) (2011). New perspectives on Yugoslavia: Key issues and controversies. New York: Routledge.

Dragović-Soso, J. (2002). Saviours of the nation: Serbia's intellectual opposition and the revival of nationalism. London: Hurst \& Co.

Dragović-Soso, J. (2008). Why did Yugoslavia disintegrate? An overview of contending explanations. I L. J. Cohen, \& J. Dragović-Soso (Red.), State collapse in south-eastern Europe: New perspectives on Yugoslavia's disintegration (s. 1-39). West Lafayette: Purdue University Press.

Gagnon, V. P. Jr. (2004). The myth of ethnic war: Serbia and Croatia in the 1990s. Ithaca: Cornell University Press. Glenny, M. (1992). The fall of Yugoslavia: The third Balkan war. London: Penguin Books.

Goldstein, I. (2003). Hrvatska povijest. Zagreb: Novi liber.

Gordy, E. (1999). Culture of power in Serbia: Nationalism and the destruction of alternatives. University Park, PA: Pennsylvania State University Press.

Goulding, D. J. (2002). Liberated Cinema:The Yugoslav Experience 1945-2001. Bloomington: Indiana University Press.

Harm, R. K. (2014, 14. juni). A history that never happened: The Yugoslav space program. Balkanist. Hämtat 06. november 2020 från http://balkanist.net/a-history-that-never-happened-the-yugoslav-space-program

Hayden, R. M. (2013). From Yugoslavia to the western Balkans: Studies of a European disunion 1991-2011. Leiden: Brill.

Hight, C. (2008). Mockumentary: A call to play. IT. Austin \& W. de Jong (Red.), Rethinking documentary: New perspectives and practices (s. 204-16). New York: McGraw-Hill/Open University Press.

Johnstone, D. (2003). Fools' crusade:Yugoslavia, NATO, and western delusions. London: Pluto Press.

Jović, D. (2003).Yugoslavism andYugoslav communism: From Tito to Kardelj. I D. Djokić (Red.), Yugoslavism: Histories of a failed idea, 1918-1992 (s. 157-81). London: C. Hurst \& Co. Publishers.

Jović, D. (2008). Yugoslavia: A state that withered away. West Lafayette: Purdue University Press.

Jönsson, M. (2004). Film och historia: Historisk Hollywoodfilm 1960-2000. Lund: KFS.

Kaplan, R. (1993). Balkan ghosts: A journey through history. New York: St. Martin's Press.

Lampe, J. R. (2000). Yugoslavia as history: Twice there was a country. New York: Cambridge University Press. 
Lampe, J. R. (2003). The two Yugoslavias as economic unions: Promise and problems. I D. Djokić (Red.), Yugoslavism: Histories of a failed idea, 1918-1992 (s. 182-95). London: C. Hurst \& Co. Publishers.

Levi, P. (2007). Disintegration in frames: Aesthetics and ideology in the Yugoslav and post-Yugoslav cinema. Stanford: Stanford University Press.

Liehm, M \& Liehm, A. J. (1977). The most important art: Soviet and east European film after 1945. Berkeley: University of California Press.

Lipkin, S. N., Paget, D. \& Roscoe, J (2006). Docudrama and mock-documentary: Defining terms, proposing canons. I G. D. Rhodes \& J. P. Springer (Red.), Docufictions: Essays on the intersection of documentary and fictional filmmaking (s. 11-26). Jefferson, NC: McFarland \& Co.

Little, A. \& Silber, L. (1996). Yugoslavia: Death of a nation. New York: TV Books.

Luković, P. (1989). Bolja prošlost: prizori iz muzičkog života Fugoslavije 1940-1989. Beograd: Mladost.

Magaš, B. (1993). Destruction of Yugoslavia. London: Verso.

Munitić, R. (1999). SrpskiVek Filma. Beograd: Institut za film.

Nichols, B. (1991). Representing reality: Issues and concepts in documentary. Bloomington: Indiana University Press.

Ognjanović, D \& Velisavljević, I. (Red.) (2008). NOVI KADROVI: Skrajnute vrednosti srpskog filma, Beograd: Clio.

Ostojić, S. (1977). RAT REVOLUCIFA EKRAN. Zagreb: Spektar.

Pajkić, N. (2009). Antologija Nepročitanih scenarija. Beograd: Filmski Centar Srbije.

Pavlović, Ž. (1996). Đavolji film. Novi Sad: Prometej.

Pavlowitch, S. (1988). The improbable survivor: Yugoslavia and its problems, 1918-1988. Columbus: Ohio University Press.

Perica, V. (2002). Balkan idols: Religion and nationalism in Yugoslav states. Oxford: Oxford University Press.

Petrović, A. (1971). Novi Film. Beograd: Institut za film.

Plantinga, C. (1987). Defining documentary: Fiction, non-fiction, and projected worlds. Persistence of Vision, $5,44-54$.

Polimac, N. (2016, 28. april). Kako je Tito nasamario SAD. Futarnji List.

Pond, S. (2016, 16. April). "Docu-fiction" movie confuses Tribeca Film Festival audience - and that's the point. The Wrap. Hämtat 06. november 2020 från https://www.thewrap.com/docu-fiction-movieconfuses-tribeca-film-festival-audience-and-thats-the-point/

Potočnik, H. (1929). DAS PROBLEM DER BEFAHRUNG DES WELTRAUMS. DER RAKETEN-MOTOR. Berlin: Richard Carl Schmidt \& Co.

Poulton, H. (2003). Macedonians and Albanians as Yugoslavs. I D. Djokić (Red.), Yugoslavism: Histories of a failed idea, 1918-1992 (s. 115-35). London: C. Hurst \& Co. Publishers.

Radić, D. (2016, 9. maj). Problema uistinu ima. Novosti.

Ramet, S. P. (1992). Nationalism and federalism in Yugoslavia, 1962-1991. Bloomington: Indiana University Press.

Ramet, S. P. (2002). Balkan Babel: The disintegration of Yugoslavia from the death of Tito to the fall of Milošević. Boulder: Westview Press.

Raspor, V. (1950). Problemi naše filmske umjetnosti i zadaci saveza filmskih radnika Jugoslavije. Filmska Kultura, 1, s. 1-14.

Resic, S. (2006). En historia om Balkan: Fugoslaviens uppgång och fall. Lund: Historiska Media.

Robinson, S. P. (2016, 12. augusti). You can almost taste the authenticity in Žiga Virc's “documentary" Houston, we have a problem! Montages. Hämtat 06. november 2020 från https://montagesmagazine.com/2016/08/ you-can-almost-taste-the-authenticity-in-ziga-vircs-documentary-houston-we-have-a-problem/

Roscoe, J. \& Hight, C. (2001). Faking it: Mock documentary and the subversion of factuality. Manchester: Manchester University Press.

Rosenstone, R. A. (2000). The historical film: Looking at the past in a postliterate age. I M. Landy (Red.), The historical film: History and memory in media (s. 50-66). New Brunswick: Rutgers University Press.

Sindbæk, T. (2012). Usable history? Representations of Yugoslavia's difficult past - from 1945-2002. Aarhus: Aarhus University Press.

Škrabalo, I. (1998). 101 Godina Filma u Hrvatskoj 1896-1997: Pregled Povijesti Hrvatske Kinematografije. Zagreb: Nakladni Zavod Globus.

Solash, R. (2012, 18. januari). Experts unconvinced by trailer claiming secret U.S.-Yugoslav space pact. Radio Free Europe/Radio Liberty. Hämtat 06. november 2020 från https://www.rferl.org/a/video_claims_secret_ us-yugoslavia_space_pact/24456127.html

Stojiljković, M. (2016, 13. maj). Houston, we have a problem: Istina ili pažljivo složena alternativno-istorijska fantazija? Sasvim je svejedno. Lupiga. Hämtat 06. november 2020 från https://www.lupiga.com/filmovi/ 


\section{2 | SANJIN PEJKOVIĆ}

houston-we-have-a-problem-istina-ili-pazljivo-slozena-alternativno-istorijska-fantazija-sasvim-jesvejedno

Taylor, A. (2012, 18. januari). This documentary claims that communist Yugoslavia played a secret role in putting a man on the moon. Business Insider. Hämtat 06. november 2020 från https://www.businessinsider. com.au/yugoslavia-moon-jfk-space-tito-2012-1

Tirnanić, B. (2008). Crni talas. Beograd: Filmski Centar Srbije.

Velikonja, M. (2003). Slovenia's Yugoslav century. I D. Djokić (Red.), Yugoslavism: Histories of a failed idea, 1918-1992 (s. 84-99). London: C. Hurst \& Co. Publishers.

Vojnov, D. (2016, 25. maj). Klub ljubitelja Milivoja Jugina. Before After. Hämtat 06. november 2020 från https://www.beforeafter.rs/drustvo/klub-ljubitelja-milivoja-jugina/

Vučetić, R. (2011). Soviet cosmonauts and American astronauts in Yugoslavia: Who did the Yugoslavs love more? I E. Maurer, J. Richers, M. Rüthers \& C. Scheide (Red.), Soviet space culture: Cosmic enthusiasm in socialist societies (s. 188-205). New York: Palgrave MacMillan.

Vučetić, R. (2012). Koka-kola socijalizam. Amerikanizacija jugoslovenske popularne kulture šezdesetih godina XX veka. Beograd: Službeni glasnik.

Wachtel, A. B. (1998). Making a nation, breaking a nation: Literature and cultural politics in Yugoslavia. Stanford: Stanford University Press.

West, R. (2009). Tito and the rise and fall of Yugoslavia. London: Faber and Faber.

Woodward, S. L. (1995). Balkan tragedy: Chaos and dissolution after the Cold War. Washington DC: The Brookings Institution.

\section{Filmer}

Bob Roberts (Tim Roberts, 1992).

David Holzman's diary (James Mc Bride, 1967).

Forgotten silver (Peter Jackson, 1995).

Houston, we have a problem! (Boštjan Virc, 2016).

Las Hurdes: Tierra sin Pan Luis (Land utan bröd, Luis Buñuel, 1932).

Man bites dog (Rémy Belvaux, André Bonzel \& Benoit Poelvoorde, 1992).

Star wars (Stjärnornas krig, George Lucas, 1977).

The Blair witch project (Daniel Myrick \& Eduardo Sánchez, 1999).

The Rutles: All you need is cash (Eric Idle \& Gary Weis, 1978).

This is spinal tap (Rob Reiner, 1984).

\section{Tv-program}

Nyheter, HRT 1 18/1 2012.

\section{Radioprogram}

War of the worlds (Orson Welles, 1938).

\section{Konstverk}

La trahison des images (Bildernas opålitlighet, René Magritte, 1928-29). 